\title{
A Review on the Neurological Manifestations of COVID-19 Infection: a Mechanistic View
}

\author{
Hamid Soltani Zangbar ${ }^{1,2} \cdot$ Ali Gorji ${ }^{3,4,5} \cdot$ Tahereh Ghadiri $^{1,5}$ (1) \\ Received: 30 May 2020 / Accepted: 23 September 2020 / Published online: 26 September 2020 \\ (C) Springer Science+Business Media, LLC, part of Springer Nature 2020
}

\begin{abstract}
There is increasing evidence of neurological manifestations and complications in patients with coronavirus disease 19 (COVID-19). More than one-quarter of patients with COVID-19 developed various neurological symptoms, ranging from headache and dizziness to more serious medical conditions, such as seizures and stroke. The recent investigations introduced hyposmia as a potential early criterion of infection with COVID-19. Despite the high mortality and morbidity rate of COVID-19, its exact mechanism of action and pathogenesis is not well characterized. The spike protein of severe acute respiratory syndrome coronavirus 2 (SARS-CoV-2) could interact with angiotensin-converting enzyme 2 (ACE2) in the endothelial, neural, and glial cells. In the present study, we reviewed the most common neurological manifestations and complications that emerged after infection with the SARS-CoV-2 and discussed their possible relation to the expression and function of ACE2. Comprehensive and detailed studies are required to uncover how this virus invades the neural system as well as other critical organs.
\end{abstract}

Keywords COVID-19 · ACE2 - Vascular · Brain · Angiotensin · Cytokine

\section{Introduction}

While the first infection by the coronavirus disease 19 (COVID-19) had emerged in late December 2019 in Wuhan, China, COVID-19 has spread fast across several regions, and in less than 1 month after the first report, COVID-19 was an outbreak as well as the first line of the public health concern worldwide. Recent coronavirus is knowns as "the new coronavirus," "2019-nCoV," and "severe acute respiratory syndrome coronavirus 2 (SARS-CoV-2)" [1, 2]. The World Health Organization (WHO) officially renamed the disease as

Tahereh Ghadiri

ghadirit@tbzmed.ac.ir

1 Department of Neuroscience and Cognition, Faculty of Advanced Medical Sciences, Tabriz University of Medical Sciences, Tabriz, Iran

2 Student Research Committee, Tabriz University of Medical Sciences, Tabriz, Iran

3 Epilepsy Research Center, Department of Neurology and Institute for Translational Neurology, Westfälische Wilhelms-Universität Münster, Münster, Germany

4 Neuroscience Research Center, Mashhad University of Medical Sciences, Mashhad, Iran

5 Shefa Neuroscience Research Center, Khatam Alanbia Hospital, Tehran, Iran
COVID-19. Coronaviruses (CoVs), such as severe acute respiratory syndrome (SARS-CoV) and the Middle East respiratory syndrome (MERS-CoV), can induce miscellaneous systemic infections [3]. CoVs can cross the animal species and in humans may lead to severe morbidity and mortality [4-6]. As of September 5, 2020, approximately 26 million cases of the COVID-19 have been confirmed worldwide, resulting in more than 870,000 deaths worldwide [7]. While the number of confirmed cases is duplicated within a few weeks, it reached 12,500 000 COVID-19 cases in Africa by September 5, 2020 [8].

\section{COVID-19 Genome Structure and Proteins}

The complete genome of "SARS-CoV-2," with ID NC_045512, is available in the National Center for Biotechnology 1 (NCBI) database. This coronavirus is constituted of a 29,903 base pairs single-stranded RNA (ss-RNA). The virus causing COVID-19 is a SARS-like coronavirus that had previously been reported in bats in China [1]. Singlestrand (positive-sense) of COVID-19 RNA is associated with a nucleoprotein within a capsid comprised of matrix protein. The envelope contains glycoprotein projections. Coronaviruses have the largest genomes $(>26 \mathrm{~kb})$ among all known RNA viruses. While typically $\mathrm{CoV}$ genome carries at least six open reading frames (ORFs), variable numbers of small ORFs are present between the various conserved genes 
and downstream to the nucleocapsid gene in different coronavirus lineages. This diversity in ORFs could result in various protein products [9]. Most important structural proteins that encoding by viral genome include spike (S), membrane (M), envelope (E), and nucleocapsid (N) proteins (Fig. 1). In addition to these common proteins, discrete $\mathrm{CoVs}$ encode their specific proteins, to provide genomic maintenance and virus replication. The glycoprotein, a main structural protein of the membrane, is a three times membrane spanning with an extracellular short NH2-terminal domain and conversely an intracellular long $\mathrm{COOH}$ terminus. The next protein, the spike protein, is a type I membrane glycoprotein that induces neutralizing antibodies. Envelope proteins probably take part in the formation and composition of the viral membrane via interaction with other elements. The E-protein is an integral protein containing 76-109 amino acids, $35 \alpha$-helices, and 40 loops, weighing between 8.4 and $12 \mathrm{kDa}$. The hydrophobic region of E-protein can generate an ion-conductive pore in membranes via oligomerization and is involved in virus assembly, budding, envelope formation, and pathogenesis. The conductance of ion through the E-protein channel affects membrane potential and seems to be a novel route linked to virus pathogenesis [10]. Intracellular responses are mainly emerged due to the penetration of M- containing particles. Under specific conditions, CoVs can grow and form spikeless, noninfectious virions.

\section{Neurological Manifestations of COVID-19 Infection}

The hallmark of SARS-CoV-2 infection is severe acute respiratory manifestations. However, it was recently documented



Fig. 1 Schematic representation of SARS-CoV-2 viral structure including single-strand RNA, spike protein, envelope protein, and membrane protein that, in addition to systemic and respiratory symptoms, some patients may experience neurologic symptoms $[2,11]$. Based on a retrospective case series study in Wuhan, China, 36.4\% (78/214) of patients with COVID-19 developed neurological symptoms, including headache, nausea or vomiting, fatigue, dizziness, impaired consciousness, acute cerebrovascular problems, ataxia, and seizures [12-14]. Hyposmia and hypogeusia are the fairly consistent symptoms of COVID-19 infection [15]. By progress in our knowledge regarding the pathophysiology of COVID-19, it has been suggested that hyposmia could be one of the key early symptoms of COVID-19 infection [16]. Mao and colleagues indicated that severely affected patients are more prone to develop neurological damage than mild or moderate cases. It must be mentioned that a percent of COVID-19 suffering individuals developed life-threatening conditions, such as acute ischemic stroke (5\%), cerebral venous sinus thrombosis $(5 \%)$, and cerebral hemorrhage (5\%) [11]. Postmortem examination of patients with COVID-19 has revealed brain tissue edema and partial neuronal degeneration [17]. Furthermore, the involvement of the central nervous system (CNS) by SARS-CoV-2 has been reported in a subject with viral encephalitis [18]. In keeping with a previous report, a case study claimed that for the first time, they had found an association between frequent seizures and COVID-19 in a young patient. Recurrent seizures could be due to encephalitis and viral invasion to the brain or the toxic effect of inflammatory cytokines [19].

The alteration of angiotensin-converting enzyme 2 (ACE2) receptor expressions might affect the route of virus invasion and pathogenicity of the COVID-19 and may be involved in the transmissibility and severity of disease [20]. Given the various evidence of neurological involvement following SARS-CoV-2 infection, herein, we review the implication of ACE2 in some neurological complications following COVID19 infection. In the next sections, we focused on the nervous system implications of the current virus.

\section{How Does COVID-19 Invade the Nervous System?}

The presence of RNA and protein particles of viruses in the CNS specimens including fluid or parenchyma implies the possibility of a direct invasion of the nervous system by viruses [2]. Indeed, researchers have approved that several viruses (e.g., herpes simplex and herpes zoster) infect either sensory ganglia or motor nerve terminals and then are transmitted to the remote parts of the brain by cellular motor proteins, dynein, and kinesins [2]. Additionally, hemagglutinating encephalomyelitis virus (HEV) and a single-stranded RNA beta coronavirus, in the primary motor cortex of infected rats, have been detected [21]. Moreover, SARS virus genome sequences have been detected in the 
brain. According to the clinical and laboratory findings, SARS-CoV-2 (COVID-19) also is a neurotropic virus and can invade nervous tissues, and coating-mediated endo/ exocytosis can be a possible route of entry to enter and transmit within the cells [21].

A few theories regarding the way for viral entry into the CNS, particularly the brain, and its pathophysiological mechanisms have been proposed. So far, the most widely accepted theory was that COVID-19 directly attacks the CNS via the olfactory nerve. It has been shown that $\mathrm{CoVs}$ reach the cerebrospinal fluid (CSF) through the olfactory tract a week after the contamination of nasal cells [21]. Interestingly, after the cut of the olfactory bulb, invasion of CoVs into the CNS was sparse in mice [2, 22]. However, based on the current knowledge regarding SARS-CoV-2, direct invasion of the CNS by this virus is controversial, and other routes than the olfactory system should be also considered [23].

ACE2 and angiotensin II (Ang II), the members of the renin-angiotensin system (RAS), are expressed within neurons and astrocytes in different brain regions as well as in the cerebral circumventricular organs and cerebrovascular endothelial cells and play a crucial role in the maintenance of neuroendocrine and autonomic systems, such as the regulation of water and sodium balance, vascular autoregulation, and cerebral blood flow [24, 25]. ACE2 is expressed in different brain structures, particularly in nuclei implicated in the central regulation of cardiovascular function, such as the brainstem, as well as in non-cardiovascular regions, like the motor cortex and raphe [26]. Genetic manipulations in the expression of ACE2 in the whole brain or certain hypothalamic nuclei resulted in a varied pattern of dysfunctions ranging from metabolic and behavioral impairments to disturbed serotonin synthesis and neurogenesis [27].

ACE2 was detected as a functional receptor for the SARS$\mathrm{CoV}$ infection [28]. A growing body of evidence suggests ACE2 as a receptor for spike protein of SARS-CoV-2 [2, 21, 25, 29-31]. In addition to ACE2, another proposed target for viral spike protein is CD147 expressing by non-neural cells $[32,33]$. Viral spike protein virus may bind to ACE2 and/or CD147 on the host cell and propagate among adjacent cells. CD147, also known as extracellular matrix metalloproteinase inducer, was identified as a red blood cell receptor for the human malaria parasite, Plasmodium falciparum [33]. For this reason, drugs that interfere in the spike protein/CD147 interaction or CD147 expression have been proposed to be beneficial for the control of COVID-19 infection. A reduction of viral load and an improvement of respiratory dysfunction in hospitalized cases have been reported after treatment with azithromycin, presumably via interaction with the CD147 receptor [33]. Given the lack of CD147 in the brain tissue, it likely mediates the CNS damage via indirect mechanisms. However, further findings regarding the effectiveness of azithromycin are controversial [34]. In a study on hospitalized patients with COVID-19, the treatment with hydroxychloroquine and/or azithromycin did not reduce mortality [35]. The more recent report of WHO also confirms that treatment with hydroxychloroquine, another promising drug, does not lower the number of death among hospitalized COVID-19 patients [8]. More evidence is needed to conclude exact antiviral clearance and clinical benefits with the abovementioned drugs in patients with COVID-19 [34, 36].

Although there is rare evidence that $\mathrm{CoVs}$, especially SARS-CoV-2, implicate the nervous system indirectly through the blood circulation pathway [2], whenever the COVID-19 virus reaches the general circulation employing the endothelial or nasal cavity or respiratory epithelial cells and can induce a huge inflammatory response and interrupt the integrity of the blood-brain barrier (BBB). Next, the virus can pass into the cerebral circulation and viral spike protein interacts with ACE2 expressed in the capillary of cerebral circumventricular organs or interrupted BBB [2]. It has been suggested that viral invasion and penetration occur mainly through ACE2 [2, 22, 25, 27-29]. Thus, in the following chapters, we first introduce the RAS and then discuss ACE2 distribution and function in the CNS. Finally, we explain how the RAS axis dysregulation is involved in the pathobiology of SARS-CoV-2.

\section{RAS and Brain}

The RAS primarily is an endocrine cascade that regulates blood pressure (BP), vascular wall resistance, and electrolyte balance. Besides its cardiovascular function, this elegant system also plays a significant role in the promotion and maintenance of inflammation and indirectly can affect cognitive function [37].

Renin, a protease secreting by the kidney, catalyzes the first step of the RAS cascade. This enzyme cleaves the angiotensinogen (Agt) secreted by the liver, to produce angiotensin I (Ang I) [38]. Moreover, renin has been recognized within astrocytes and neurons. Most of the brain Agt is secreted by astrocytes that progress into multiple natural peptides [39]. The ACE converts the Ang I to Ang II, a potent vasoconstrictor, and Ang II stimulates Ang II receptor type1 (AT1R), enhancing BP, inflammation, and even neurodegeneration [38]. Thus, chronic activation of RAS and the increase in Ang II level may activate AT1R, leading to inflammation, fibrosis, and hypertension due to excessive vasoconstriction and increased renal sodium absorption (Fig. 2a). Furthermore, several studies have reported that excessive activation of local RAS in the brain may be implicated in neurodegeneration due to neuroinflammation and excessive oxidative stress. For example, activation of AT1R by elevated Ang II in the brain tissue perturbs cognitive function, possibly due to increased oxidative stress, neuroinflammation, and cell death. Consequently, the ACE inhibitors (ACEIs) and Ang II 
a

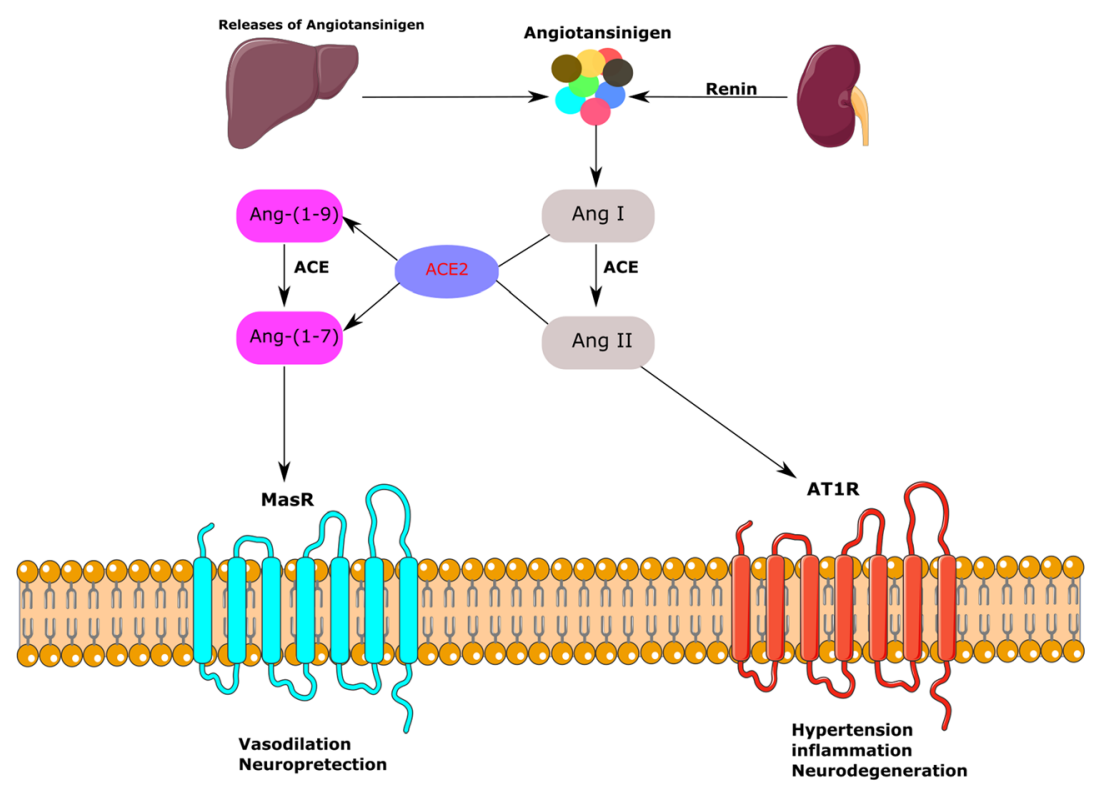

b

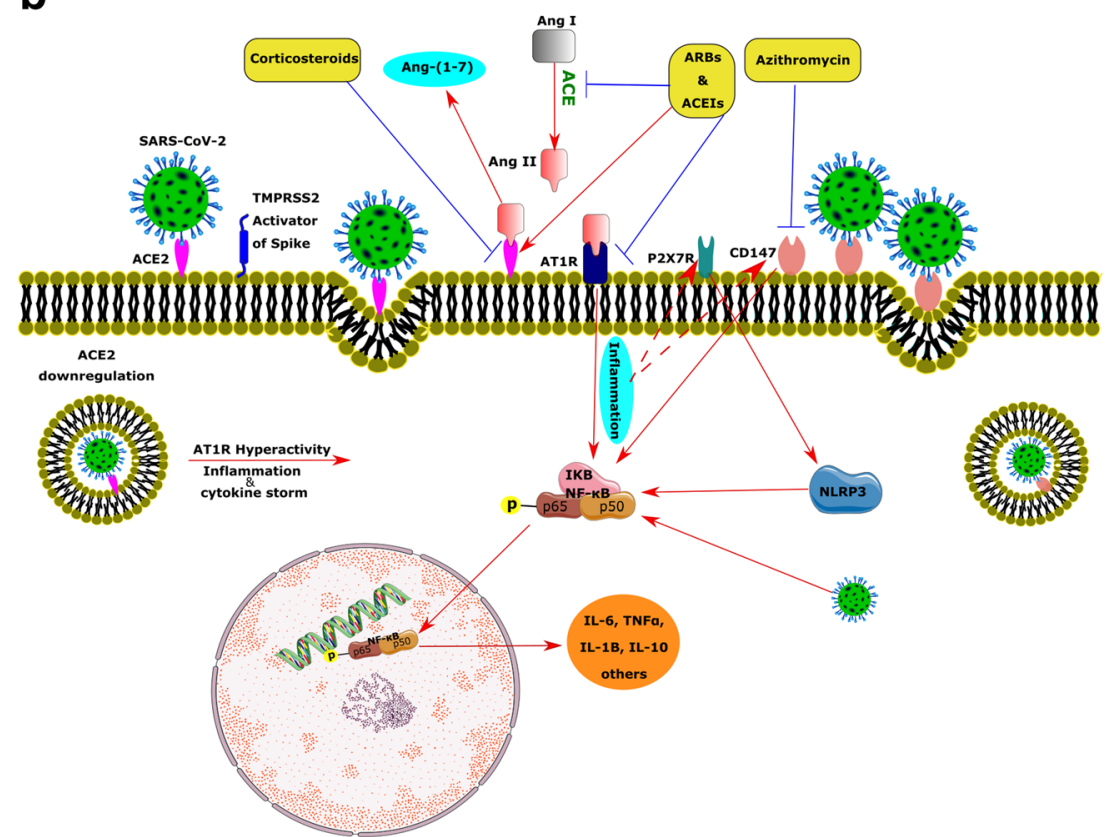

Fig. 2 Illustration of the renin-angiotensin system (RAS) arms including members and interactions in the normal and pathologic states under SARS-CoV-2 infection in addition to the ACE2/viral spike protein interaction and consequences. (a) The renin converts the angiotensinogen to angiotensin I (Ang I); consequently, Ang II is produced via the action of (ACE) on Ang I. Ang II attaches to the Ang II type 1receptor (AT1R) and drives hypertension, inflammation, and neurodegeneration. ACE produces Ang-(1-7) from either Ang I or Ang II. Then, Ang-(1-7) acts on the Mas receptor (MasR), Ang-(1-7)/MasR axis, to induce anti-inflammatory, vasodilation, and neuroprotection. (b) Beyond the homeostatic role of ACE2 via the RAS, it acts as a receptor for SARS-CoV-2 spike protein. The spike protein of the SARS-CoV-2, via activation of
TMPRSS2, binds to the ACE2 receptor on the cell surface. Internalization of the ACE2 receptor by SARS-CoV-2 downregulates the ACE2 and may induce a huge inflammatory response through the overactivation of ATR1. In the course of inflammation, the P65 subunit of NF-kB becomes phosphorylated and triggers the extra release of cytokines. CD147, another potential receptor for SARS-CoV-2, and $\mathrm{P} 2 \mathrm{X} 7$ are assumed to be involved in the cytokine via the NLRP3 inflammasome. Anti-hypertension drugs like ARBs and ACE inhibitors as well as elevate anti-inflammatory agents such as corticosteroids can downregulate the expression of ACE2. AT1R, angiotensin 1 receptor; ACE, angiotensin-converting enzyme; RAS, renin-angiotensin system; TMPRSS2, transmembrane protease serine 2 
receptor blockers (ARBs) improve cognition by reversing these alterations [40]. Both Ang II and AT1R receptors are detectable at nerve terminals of several nuclei in the brain, including the ventrolateral medulla, nucleus tractus solitarius, paraventricular nucleus, and subfornical organ (SFO) [39].

ACE2, a member of the membrane-bound carboxydipeptidase family, is one of the key components and a new member of RAS as well as the regulator of BP [41]. The current enzyme degrades Ang II to Ang-(1-7), an effective 7-amino acid peptide. Furthermore, ACE2 hydrolyzes the Ang I to Ang-(1-9), and ACE degrades Ang-(1-9) to Ang-(1-7). Ang-(1-7) consequently works upon the Mas receptor (MasR) and has contrasting actions to Ang II, such as vasodilation and neuroprotection. ACE2, Ang-(1-7), and MasR form a new arm for this system (Fig. 2a) [42]. Several investigations support the modulatory role of ACE2 products, such as Ang-(1-7), in the brain. Not surprisingly, expression of Ang-(1-7) is mainly located in nuclei related to BP regulation, such as the brainstem and the hypothalamus, and exerts synergistic or antagonistic effects on Ang-II. Ang-(1-7) has been shown to modulate cardiac baroreflex responsiveness [26]. Overexpression of the abovementioned central RAS members has been shown to elevate the ACE2 protein level in the SFO and affect its expression in the brainstem [43]. Therefore, ACE2 seems to provide a compensatory mechanism to limit brain RAS hyperactivity. In agreement with this, reducing of AT1R mRNA by a gene silencing approach was associated with a reduction of ACE2 mRNA in the brainstem [44]. In addition, ACE2 participates in the metabolism of some non-RAS peptides, such as hypertensive Apelin-13, neurotensin, and hypotensive bradykinin fragments. Genetic studies have been mapped the ACE2 gene in a hypertensionrelated quantitative trait locus on the $\mathrm{X}$ chromosome. Besides, several studies have shown a strong association of the ACE2 gene polymorphism with hypertension and hypertrophic cardiomyopathy, coronary heart disease, and myocardial infarction $[45,46]$.

\section{ACE2 Distribution in the Brain}

Low levels of ACE2 mRNA have been shown in the human brain using quantitative real-time RT-PCR two decades ago [47]. Furthermore, ACE2 protein was exclusively observed in the endothelial and arterial smooth muscle cells of brain vessels by immunohistochemistry technique [41]. Later, in vitro studies using brain primary cell cultures reported the expression of ACE2 predominantly in the glial cells [48]. In contrast, another study exhibited ACE2 protein and mRNA mostly in the cytoplasm of neuronal cell bodies of mice. Furthermore, profound amounts of ACE2 have also been found in both the central glial substance and in the CSF of human samples [49].

Widespread distribution of ACE2 has been shown throughout the brain, especially in centers involved in the central regulation of cardiovascular function like the brainstem neurons, as well as in non-cardiovascular areas such as the motor cortex and raphe nucleus [50]. In further work, the presence of ACE2 mRNA and protein in the mouse brainstem was also confirmed [44].

According to the data obtained from transgenic mice, ACE2 was significantly high in the SFO. Moreover, a correlation between the ACE2 mRNA and the expression of various proteins in of the nucleus tractus solitaries, the dorsal vagal nucleus, and the caudal ventrolateral medulla has been reported [50], suggesting a crucial role of ACE2 in the modulation of autonomic nervous system. The expression of ACE2 has been also shown in the olfactory system and other important cerebral regions, such as the brain ventricles and the substantia nigra as well as areas that are directly or indirectly related to the olfactory pathways, including the hypothalamic nuclei, the amygdala, the hippocampus, and the frontal cortex [21].

\section{ACE2 as a Receptor for SARS-CoV-2}

In addition to the olfactory system, ACE2 considerably is expressed by epithelial cells of the oral, nasal, and respiratory tract mucosa [51,52], supporting this idea that ACE2 could be a potential receptor that mediates SARS-CoV2 entry into the cells $[2,23,53]$. As mentioned above, ACE2 has been detected in glial cells and neurons of various brain areas and through the hypothalamus and other nuclei indirectly could make an extra link to the olfactory pathway (Fig. 3a). Nonetheless, how SARS-CoV-2 exactly reaches the CNS through the olfactory pathway is still unknown [23].

The interaction of viral spike protein and the ACE2 is more complicated than a simple lock-and-key interaction, and other presumed molecules are involved in the process allowing SARS-CoV-2 to invade cells (Fig. 2b). In this scene, Furin and the transmembrane protease serine 2 (TMPRSS2) are two key players [54]. TMPRSS2 locating in the cell membrane primes the spike protein to facilitate viral uptake by ACE2. During the virus/receptor interaction, viral spike protein is cleaved by Furin $[55,56]$.

Co-expression of ACE2 and TMPRSS2 in epithelial cells but not in sensory neurons of the olfactory system suggests that SARS-CoV-2-induced anosmia, and other olfactory disturbances are related to non-neuronal cells [57]. In contrast to these data, a study using IHC and gene analyses demonstrated that ACE2, TMPRSS2, and Furin are co-expressed in the respiratory and the olfactory mucosa, particularly in the supporting cells of the olfactory epithelium and Bowman's glands. This study also has detected ACE2 in the olfactory receptor neurons along with olfactory bulb neurons and concluded that the impairment of the sense of smelling can be due to neuronal dysfunction. Finally, they declared that direct assault of the olfactory receptor neurons by SARS-CoV-2 is unexpected, while these cells only express ACE2, but not 
Fig. 3 Direct invasion of CNS by SARS-CoV-2 through the olfactory system. a Angiotensinconverting enzyme 2 (ACE2) expresses in the sensory neurons of the olfactory bulb. Following entry of SARS-CoV-2 to the olfactory epithelium, it could pass from the olfactory epithelium to bulb and tract in a trans-synaptic manner and reach CNS retro-/ anterogradely. b ACE2 also is present in the vascular endothelium, pericytes, and astrocytes of circumventricular organs along with parenchymal neuron and glial cells of the brain. Systemic complications of COVID-19 may interrupt the integrity of BBB thereby facilitate its invasion to the cerebrum. c Considering that ACE2 is expressed in both astrocytes and neurons, once neural cells are contaminated by the virus, it can easily replicate and distribute in the brain. BBB, blood-brain barrier

\section{C}
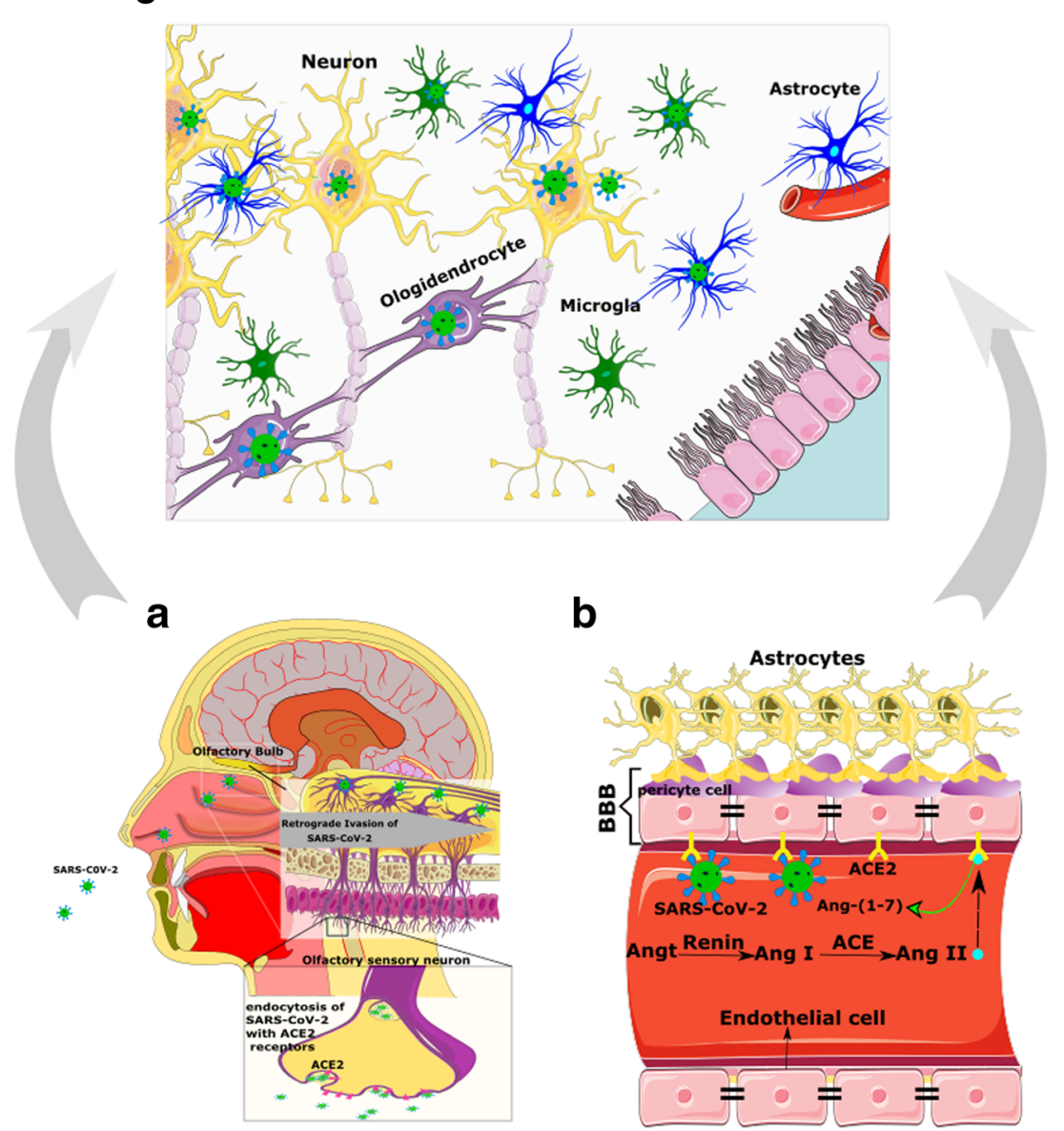

b

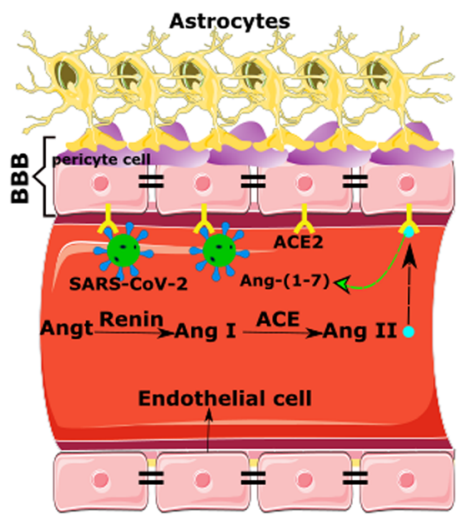

TMPRSS2 or Furin [54]. Therefore, except for direct infection of olfactory neurons, other explanations should be considered for anosmia or hyposmia in patients with COVID-19 (Fig. 3) [21].

Likewise, ACE2 and TMPRSS2 at low levels in human horizontal basal cells (HBCs) have been detected [57]. HBCs are progenitors of the olfactory epithelium and are divided continually to replace sensory neurons during adulthood [58]. Hence, olfactory sensory neurons originated from infected HBCs may be loaded by SARS-CoV-2 and deliver the virus to the olfactory cortex through the olfactory bulb [21]. It must be emphasized that besides the olfactory system, other routes of entry into the CNS should not be neglected [23].

Considering that ACE2 is expressed in the vascular endothelium, pericytes, cerebral neurons, astrocytes, and oligodendrocytes [23, 59], SARS-CoV-2 may break the BBB and invade the CNS by assailing the vascular system. Furthermore, SARS-CoV-2 by binding to ACE2 may raise BP in the brain, enhance the permeability of $\mathrm{BBB}$, and increase the risk of stroke [60, 61] (Fig. 3B and Fig. 4). Thus, apart from probable direct invasion of neural cells by COVID-19, chronic depletion of brain ACE2 due to occupying by viral particles and perturbing the balance of ACE/ACE2 may also contribute to the neurological manifestations of COVID-19.

\section{ACE2 and Cytokine Storm, the Main Mechanism of COVID-19 Complications}

In the healthy state, the ACE2/MasR axis inhibits the proinflammatory actions of ACE/Ang II/AT1R axis by degrading Ang II along with producing Ang-(1-7) and reduces the expression of mitogen-activated protein kinases (MAPK), nuclear factor kappa B (NF-kB), and inflammatory factors, such as interleukin-6 (IL-6), tumor necrosis factor $\alpha$ (TNF $\alpha$ ), and IL8 [62]. On the contrary, hyperactivation of the RAS can induce inflammation due to the release of profibrotic cytokines, such as transforming growth factor-beta (TFG- $\beta$ ), through AT1R/ACE arm. In addition, high levels of Ang II and hyperactivation of AT1R activate the complement cascade, including C5a and C5b-9 [63-65].

Under pathologic conditions, such as COVID-19 infection, after binding of viral spike protein to ACE2 in type II pneumocytes, the complex of virus/ACE2 downregulates the intracellular ACE2 and consequently enhances inflammation [62]. As a result of ACE2 downregulation, serum levels of 
Fig. 4 Stroke after the SARS$\mathrm{CoV}-2$ infection. Hypertension has been generally stated to be associated with SARS-CoV-2 disease. The reduction of ACE2 by SARS-CoV-2 provides the condition for Ang II-dependent hypertension. Raised CRP and Ddimer levels indicate a high inflammatory status and abnormality in the coagulation cascade and probably play a key role in the pathophysiology of stroke in the context of COVID-19 infection

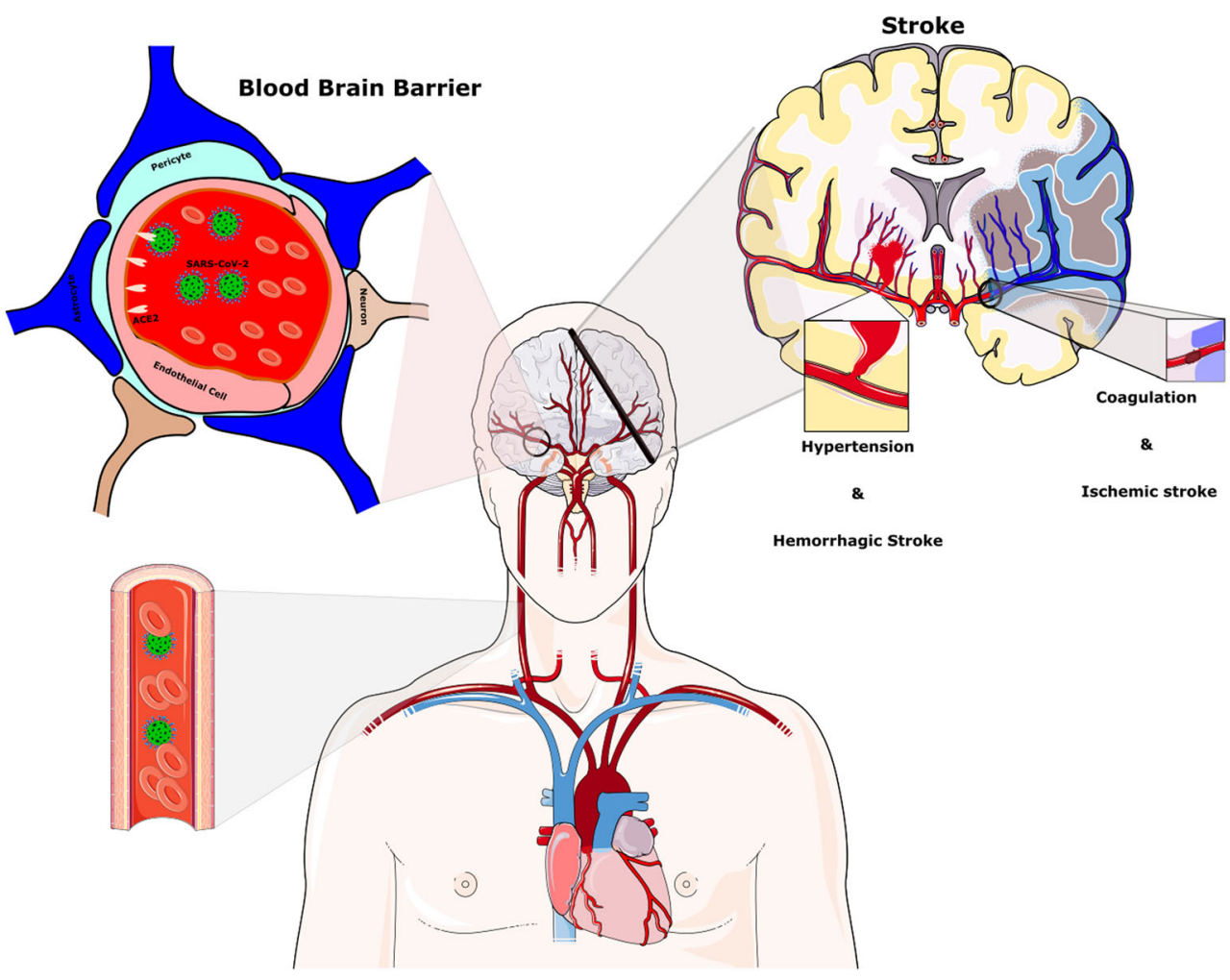

Ang II and the activity of the Ang II/AT1R axis are potentiated [62]. Furthermore, the downregulation of ACE2 leads to the activation of the NF- $\mathrm{KB}$ pathway via phosphorylation of its p65 subunit and the enhancement of IL-6, TNF $\alpha$, IL-1B, and IL-10 production. The MAPK, which plays a critical role in the release of various cytokines, including IL-1, IL-10, IL12, and TNF $\alpha$, is also modulated by Ang II [66]. Several clinical studies have indicated a marked increase of proinflammatory cytokines, like IL-2, IL-6, and TNF- $\alpha$, in severe and moderate cases of COVID-19 [67-73].

Besides, SARS-CoV-2 itself stimulates the NF- $\mathrm{kB}$ pathway independent of ACE2 through pattern recognition receptors. Predictably, this surge of cytokines in the serum triggers a cytokine storm that results in acute respiratory distress syndrome (ARDS) in severe cases of COVID-19 [62]. Furthermore, local elevated production of cytokines in the cerebral tissue can induce inflammation [73] and lead to neurologic features observed in COVID-19 patients [74]. It should be also mentioned that viral components are capable to interact with various molecules, such as pattern recognition receptors (e.g., Toll-like receptors), NF- $\mathrm{kB}$, complement cascades, certain transcription factors, and cell apoptosis mediators $[62,75]$. Following the entrance of the virus into the CNS, miscellaneous signaling pathways inside or between cells could be modified, and cerebral neurotransmitters and local hormones may be dysregulated.

Referring to the fact that COVID-19-induced ARDS is a consequence of an uncontrolled inflammatory response characterized by cytokines storm, several in vivo and in vitro experiments point to the probable implication of the purinergic ionotropic $\mathrm{P} 2 \mathrm{X} 7$ in this process. The $\mathrm{P} 2 \mathrm{X} 7 \mathrm{R}$ plays a critical role in the neuroinflammation through its potent stimulatory effects on the NLRP3 inflammasome, which consequently leads to caspase- 1 activation, IL-1 $\beta$ and IL-18 release, and macrophage down-modulation. The SARS-CoV can also directly activate the NLRP 3 inflammasome. The pharmacological blockade or genetic knockdown of the P2X7R has substantially reduced inflammatory cell infiltration, cytokine levels, and lung damage. Moreover, in the absence of P2X7R, alveolar macrophage death and pro-IL-1 $\beta$ release decreased in an in vivo model of lung inflammation. Thus, the P2X7R has been proposed as an inflammatory biomarker for COVID-19 infection [76], which may predict the outcome of neurological complications of patients with COVID-19 infection. The purinergic P2X7 receptor is widely distributed in the brain [77] and is linked to the inflammatory and neurodegenerative changes.

Considering the bold action of hyper-inflammation in the pathophysiology of SARS-CoV-2, non-steroidal anti-inflammatory drugs and corticosteroids may be an effective treatment for alleviating symptoms of COVID-19. Emerging evidence demonstrated the effectiveness of corticosteroids in the control of COVID-19-induced acute damage. However, the possibility of viral rebound or other side effects in the longterm administration of corticosteroids could not be ruled out [78]. In this regard, a randomized controlled trial reported a 
higher concentration of SARS-CoV-2 RNA in week $2 / 3$ of infection in those treated with corticosteroids. Additionally, in a pig model of respiratory CoVs infection, a few doses of dexamethasone in the acute phase of infection diminished acute pro-inflammatory response, but with prolonged administration, there was a risk of viral replication. Nevertheless, some evidence supports the beneficial effects of the limited application of anti-inflammatory drugs in the early stage of COVID-19 infection [78].

Mounting evidence implies the comorbidity of hypertension and other forms of cardiovascular diseases in severe cases of COVID-19 that are commonly treated with ACEIs and ARBs. Theoretically, ACEIs and ARBs are supposed to increase ACE2 level and subsequently the entrance of SARS$\mathrm{CoV}-2$ into the cells and lead to greater adverse outcomes, such as lung injury. However, according to the experimental studies, ACE2 was protective against lung damages. ACE2 forms anti-inflammatory Ang-(1-7) from Ang II and thus antagonizes the inflammatory action of Ang II. Moreover, ACEIs via the reduction of formation of Ang II and ARBs through the inhibition of Ang II activity and the blockade of AT1R could control the systemic inflammatory response. By the abovementioned mechanisms, these agents could prevent the development of ARDS, myocarditis, or acute kidney injury, which commonly occur in COVID-19. Furthermore, ARBs are potential candidates for the treatment of SARSCoV-2 complications. Taking into account that high level of soluble ACE2 in the serum can block viral spike protein and reduce the uptake of SARS-CoV-2 by ACE2 expressing organs, application of recombinant ACE2 is proposed as a therapeutic approach for COVID-19 [79].

In addition to the ACEIs and AT1R blockers [79], antiinflammatory drugs, like thiazolidinedione and ibuprofen, can increase the amount of ACE2 [80]. It is not clear whether the poor prognosis of COVID-19 infection in hypertensive and diabetic patients is related to their previous pharmacotherapies and molecular adjustments or due to their ACE2 profile. According to Fang et al., the vulnerability of an individual to COVID-19 could be a result of both previous therapy and ACE2 gene polymorphisms [80]. Taken as a whole, neither the exact role of hypertension nor the beneficial or the harmful effects of ACEIs or ARBs [79] along with anti-inflammatory agents on the outcomes of COVID-19 have been clarified and must be further explored.

\section{Other Possible Mechanisms}

There are several possibilities regarding pathophysiologic mechanisms by which COVID-19 affects brain function. A potential mechanism for neurological mechanisms could be related to SARS-CoV-2-induced hypoxia. Viral invasion disturbs the gas exchange by the respiratory system and leads to general hypoxia. Hypoxia induces anaerobic metabolism in the mitochondria of cerebral cells resulting in overproduction of acid. High levels of acid cause intracerebral vasodilation, brain edema, obstruction of cerebral blood flow, ischemia, and headache. As a result of continuous hypoxia, intracranial hypertension can appear. In high-risk patients with cardiovascular diseases, hypoxia may also induce the occurrence of acute ischemic stroke and neurologic symptoms (Fig. 4) [2].

Ultimately, it must be mentioned that neurologic complications could be due to secondary infection, not coronavirus itself. While the BBB is impaired because of viral infection, it is easier for other pathogens to reach the CNS. Therefore secondary intracranial infections may cause neurological involvement in patients infected with COVID-19 [2].

\section{Neurologic Manifestations of COVID-19 Infection}

After summarizing relevant pathophysiological changes of COVID-19 infection that may lead to neurologic manifestations, we describe the most common neurologic complications observed in the infected individuals.

\section{Hyposmia}

One of the common early features of contamination with COVID-19 is hyposmia [81]. The direct connection of the olfactory bulbs with the brain, penetration of COVID-19 into the brain, is expectable. While one possible mechanism is a retrograde transmission of COVID-19, through the olfactory epithelium to the brain [82], other probable routs should not be neglected. It is remembered that neuronal precursors originating from the subventricular zone (SVZ) migrate and mature through the rostral migratory system until reaching the olfactory bulb. The BBB of SVZ is more penetrable compared with other brain areas due to the lack of pericytes and astrocyte-end feet processes, which envelope the blood vessels [83]. On the other side, SARS-CoV-2 binds to ACE2 and therefore could degrade Ang II to Ang-(1-7) and increase the Ang II level in the bloodstream. It is reported that a high level of angiotensin can evoke apoptotic effects on the neural stem cells [84] and reduce the number of precursors in the SVZ and subsequently diminish the number of migrating cells to the olfactory bulb. As a result of a reduction in the replacement of new neurons in the olfactory bulb, the sense of smell can be disturbed.

\section{Seizure}

Another neurologic feature observed in patients with COVID19 is convulsive seizures [19]. In a study conducted on 70 subjects with MERS-CoV infection, the seizure was reported in $9 \%$ of the patients [85]. Additionally, seizures occurred in some patients with COVID-19 [11]. RAS has a vital role in 
several neurological conditions, including seizures. Consistently inhibition of the renin-angiotensin system prevented seizures in a rat model of epilepsy [86]. Furthermore, the expression of Ang II, AT1R, and AT2R receptors in the hippocampal formation of the patients with temporal lobe epilepsy is upregulated, supporting the potential involvement of the RAS in triggering seizures [87]. The reduction of ACE2 availability, as well as the enhancement of Ang II values and its downstream pro-inflammatory mediators in COVID-19, may contribute to the occurrence of seizures. Epileptic seizures can enhance the production of cytokines, such as IL- $1 \mathrm{~b}$ and TNF $\alpha$, which in turn regulate the pathogenesis and course of seizure attacks [10].

\section{Stroke}

Up to now, stroke is one of the most serious and fatal adverse outcomes of COVID-19 infection. Several investigations have reported the occurrence of acute cerebrovascular disease, particularly ischemic stroke in patients with severe COVID-19 infection [88-90]. These serious complications of COVID-19 are due to thrombolytic events, vascular wall defects, and cerebral hemorrhage. Approximately $6 \%$ of severe COVID19 patients developed the cerebrovascular insult in the course of disease [11]. Avula et al. have reported that four patients with PCR confirmed SARS-CoV-2 infection exhibited a radiographic verification of acute stroke [91]. Moreover, a hospitalized subject for a hidden subtle stroke with right limb weakness with low speech fluency has been diagnosed with COVID-19 [30].

Raised CRP and D-dimer levels, indicating a high inflammatory status and abnormality in the coagulation cascade, likely perform a functional task in the pathophysiology of stroke in the context of COVID-19 infection [53]. The overactivation of the complement cascade in the process of the inflammatory response by SARS-CoV-2 can lead to thrombosis (Fig. 4) [92, 93]. Besides, due to the reduction of ACE2 proteins and a further increase in Ang II, enhanced BP can raise the occurrence of stroke. In agreement with this statement, large vessel occlusion, such as the middle cerebral artery, was correlated with CoVs infection [94]. In addition, an increase in the expression of CD147 in astrocytes has been reported in an experimental stroke model [16].

\section{Ataxia}

Acute cerebellar infarction may cause lethargy, dysarthria, and ataxia [95]. Moreover, acute cerebral ataxia may coincide with immune-mediated inflammatory conditions and encephalopathies [96], which are common in the SARS-CoV-2 infection.

\section{Headache}

Headache is a common sign of various medical problems, such as viral infection and arterial hypertension. Hypertension-induced headache is usually bilateral and acute and is linked to a sharp increase in diastolic $\mathrm{BP} \geq 120 \mathrm{mmHg}$ or systolic BP $\geq 180 \mathrm{mmHg}$ [97-99]. The balance between the ACE2 and ACE is important for the regulation of BP [100]. The alteration of the ACE/ACE2 ratio in COVID-19, therefore, may increase BP and trigger headaches. Another plausible cause of headache in COVID-19 sufferers could be the surge of inflammatory cytokines, including TNF $\alpha$, IL-1, and IL-6 [101, 102]. Intracerebral hypoxia and secondary infection of cerebral tissue are other potential causes of headaches [2].

\section{Encephalopathy}

Like the majority of described conditions, encephalopathy is not a specific disease, but a symptom or syndrome accompanied by general brain dysfunction causing by organic or nonorganic roots. Due to the involvement of various organs in the SARS-CoV-2 infection, the risk of encephalopathy is very high [103]. There are several types of encephalopathy, such as hypertensive encephalopathy, hypoxic-ischemic encephalopathy, hepatic encephalopathy, and uremic encephalopathy that may be observed in patients with COVID-19.

\section{Hypertensive Encephalopathy}

The hypertensive crisis could have resulted in headaches, seizures, and perturbed consciousness [104]. Hypertensive encephalopathy occurs due to the breakdown of BBB integrity following high BP that leads to cerebral hyper-perfusion and, eventually, brain edema. In a normal state, the cerebral autoregulatory mechanism protects the BBB from hazardous systolic BP increases [105]. In contrast, remarkably fast accelerations of BP cause orthostatic plasma leakage over the capillaries [106]. Hypertension has been generally stated to be associated with SARS-CoV-2 disease [107]. The reduction of ACE2 by SARS-CoV-2 increases the risk of Ang IIdependent hypertension [108]. This may trigger a cascade that results in the hypertensive encephalopathy through the disruption of BBB integrity and cerebral hyper-perfusion.

\section{Hypoxic-Ischemic Encephalopathy}

Hypoxic-ischemic brain injury or encephalopathy (HIE) is a neurovascular and neuro-metabolic syndrome. HIE arises as an outcome of a lack of oxygen or glucose supply or changed cerebral metabolism after severe brain damage. This encephalopathy results from global hypo-perfusion or hyperoxygenation rather than from specific vascular infarction in 
a cerebral area [109]. Some cerebral regions between the anterior and middle cerebral artery may be influenced by HIE, including the basal ganglia, hippocampal formation, cerebellum, and thalamus [110]. Respiratory dysfunction following viral infection could also evoke general hypoxia and therefore induce anaerobic metabolism in the mitochondria of cerebral cells. Low $\mathrm{pH}$ grounds intracerebral vasodilation, brain edema, obstruction of cerebral blood flow, and ischemia. In highrisk patients with cardiovascular diseases, hypoxia may also terminate to acute ischemic stroke and other neurologic symptoms $[2,93]$. As mentioned, a common etiology of HIE is cardiovascular injuries, which is mutual among SARA-CoV2-infected patients [111]. ACE2 is also broadly expressed in coronary endothelial cells, cardiac fibroblasts, and cardiomyocytes [112]. Overexpression of ACE2 exerts a protective function and reverses heart failure, whereas suppression of ACE2 expression can accelerate the progress of heart failure [113].

\section{Hepatic Encephalopathy}

Hepatic anomalies and even hepatic failure after infection with COVID-19 have been reported. Hepatic damages could be due to the direct effect of SARS-CoV-2 on the liver or due to the side effects of the medications [114]. Xu and colleagues have reported steatosis and liver injury in a SARS-CoV2 patient [23]. Cardiovascular dysfunction could be another potential cause of COVID-19-related hepatic encephalopathy.

\section{Uremic Encephalopathy}

Uremic encephalopathy could be a consequence of acute or chronic renal failure after a fall in the glomerular filtration rate, which is frequently reported in patients with COVID-19. This prompts a syndrome with various symptoms, such as fatigue or seizures $[115,116]$. Some studies have reported an amplified incidence of acute renal damage following SARS-CoV-2. It is unknown that this failure is caused by virus-evoked inflammatory reactions or cardiovascular disturbance [117-119]. The kidney has an essential role in the control of acid-base balance and also is a crucial regulator of cerebral homeostasis via excretion of toxins and modification of cytokine concentrations. Uremic encephalopathy seemingly occurs following ACE/ACE2 imbalance during COVID-19 infection $[120,121]$.

\section{Conclusion}

RAS and ACE2 play crucial roles in the pathogenesis of neurologic manifestations of COVID-19 infection, presumably through their regulatory effects on blood circulation and BP. Furthermore, ACE may implicate in SARA-CoV-2-related neurologic symptoms via its modulatory effects in the inflammatory and immune responses [119]. According to the growing body of evidence, severe neurologic complications of COVID-19 infection, such as stroke, worsen COVID-19 outcomes. Further studies are warranted to investigate whether pharmacological manipulation of RAS and ACE2 may affect the course and outcomes of COVID-19.

Authors' Contributions H. S. prepared figures and contributed to the preparation of the MS. A. G. critically reviewed, revised, and contributed to the final manuscript. T. G. conceived the idea of work and wrote and revised the manuscript. All authors approved the final version of the manuscript.

\section{Compliance with Ethical Standards}

Conflict of Interest The authors declare that they have no conflicts of interest.

\section{References}

1. Baig AM, Khaleeq A, Ali U, Syeda H (2020) Evidence of the COVID-19 virus targeting the CNS: tissue distribution, hostvirus interaction, and proposed neurotropic mechanisms. ACS Chem Neurosci 11(7):995-998. https://doi.org/10.1021/ acschemneuro.0c00122

2. Wu Y, Xu X, Chen Z, Duan J, Hashimoto K, Yang L, Liu C, Yang C (2020) Nervous system involvement after infection with COVID-19 and other coronaviruses. Brain Behav Immun 87: 18-22. https://doi.org/10.1016/j.bbi.2020.03.031

3. Su S, Wong G, Shi W, Liu J, Lai AC, Zhou J, Liu W, Bi Y et al (2016) Epidemiology, genetic recombination, and pathogenesis of coronaviruses. Trends Microbiol 24(6):490-502. https://doi.org/ 10.1016/j.tim.2016.03.003

4. Zumla AI, Memish ZA (2014) Middle East respiratory syndrome coronavirus: epidemic potential or a storm in a teacup? Eur Respir Soc 43:1243-1248. https://doi.org/10.1183/09031936.00227213

5. Zowalaty M, Jarhult J (2020) From SARS to COVID-19: A previously unknown SARS-related coronavirus (SARS-CoV-2) of pandemic potential infecting humans-call for a one health approach. One Health 9(100124):10.1016. https://doi.org/10.1016/ j.onehlt.2020.100124

6. Li W, Hulswit RJ, Kenney SP, Widjaja I, Jung K, Alhamo MA, van Dieren B, van Kuppeveld FJ et al (2018) Broad receptor engagement of an emerging global coronavirus may potentiate its diverse cross-species transmissibility. Proc Natl Acad Sci 115(22):E5135-E5143. https://doi.org/10.1073/pnas.1802879115

7. WHO (2020) Numbers at a glance. https://www.who.int/ emergencies/diseases/novel-coronavirus-2019

8. WHO (2020) Rolling updates on coronavirus disease (COVID19). https://www.who.int/emergencies/diseases/novelcoronavirus-2019/events-as-they-happen

9. Orr MW, Mao Y, Storz G, Qian SB (2020) Alternative ORFs and small ORFs: shedding light on the dark proteome. Nucleic Acids Res 48(3):1029-1042. https://doi.org/10.1093/nar/gkz734

10. Boopathi S, Poma AB, Kolandaivel P (2020) Novel 2019 coronavirus structure, mechanism of action, antiviral drug promises and rule out against its treatment [published online ahead of print, 2020 Apr 30]. J Biomol Struct Dyn:1-10. https://doi.org/10. 1080/07391102.2020.1758788 
11. Mao L, Wang M, Chen S, He Q, Chang J, Hong C, Zhou Y, Wang D et al (2020) Neurological manifestations of hospitalized patients with COVID-19 in Wuhan, China: a retrospective case series study. 77(6):683-690. https://doi.org/10.1001/jamaneurol.2020. 1127

12. Cao Z, Li T, Liang L, Wang H, Wei F, Meng S, Cai M, Zhang Y et al (2020) Clinical characteristics of coronavirus disease 2019 patients in Beijing, China. PLoS One 15(6):e0234764. https://doi. org/10.1371/journal.pone.0234764

13. Guan WJ, Ni ZY, Hu Y, Liang WH, Ou CQ, He JX, Liu L, Shan H et al (2020) Clinical characteristics of coronavirus disease 2019 in China. N Engl J Med 382(18):1708-1720. https://doi.org/10. 1056/NEJMoa2002032

14. Yang X, Yu Y, Xu J, Shu H, Xia J, Liu H, Wu Y, Zhang L et al (2020) Clinical course and outcomes of critically ill patients with SARS-CoV-2 pneumonia in Wuhan, China: a single-centered, retrospective, observational study. Lancet Respir Med 8(5):475481. https://doi.org/10.1016/S2213-2600(20)30079-5

15. Bénézit F, Le Turnier P, Declerck C, Paillé C, Revest M, Dubée V, Tattevin P, Arvieux C et al (2020) Utility of hyposmia and hypogeusia for the diagnosis of COVID-19. Lancet Infect Dis 20(9):1014-1015. https://doi.org/10.1016/S1473-3099(20) 30297-8

16. Baig AM (2020) Neurological manifestations in COVID-19 caused by SARS-CoV-2. CNS Neurosci Ther 26(5):499-501. https://doi.org/10.1111/cns.13372

17. Huang C, Wang Y, Li X, Ren L, Zhao J, Hu Y, Zhang L, Fan G et al (2020) Clinical features of patients infected with 2019 novel coronavirus in Wuhan, China. Lancet 395(10223):497-506. https://doi.org/10.1016/s0140-6736(20)30183-5

18. Moriguchi T, Harii N, Goto J, Harada D, Sugawara H, Takamino J, Ueno M, Sakata H et al (2020) A first case of meningitis/ encephalitis associated with SARS-Coronavirus-2. Int J Infect Dis 94:55-58. https://doi.org/10.1016/j.ijid.2020.03.062

19. Karimi N, Razavi AS, Rouhani N (2020) Frequent convulsive seizures in an adult patient with COVID-19: a case report. Iran Red Crescent Med J 22(3):e102828. https://doi.org/10.5812/ ircmj. 102828

20. South AM, Diz DI, Chappell MC (2020) COVID-19, ACE2, and the cardiovascular consequences. Am J Phys Heart Circ Phys 318(5):H1084-H1090. https://doi.org/10.1152/ajpheart.00217. 2020

21. DosSantos MF, Devalle S, Aran V, Capra D, Roque NR, CoelhoAguiar JM, Spohr T, Subilhaga JG et al (2020) Neuromechanisms of SARS-CoV-2: a review. Front Neuroanat 14:37. https://doi.org/ 10.3389/fnana.2020.00037

22. Bohmwald K, Galvez NMS, Rios M, Kalergis AM (2018) Neurologic alterations due to respiratory virus infections. Front Cell Neurosci 12:386. https://doi.org/10.3389/fncel.2018.00386

23. Chen R, Yu J, Wang K, Howard D, French L, Chen Z, Wen C, Xu $Z$ (2020) The spatial and cell-type distribution of SARS-CoV-2 receptor ACE2 in human and mouse brain. bioRxiv. https://doi. org/10.1101/2020.04.07.030650

24. Saavedra JM (2005) Brain angiotensin II: new developments, unanswered questions and therapeutic opportunities. Cell Mol Neurobiol 25(3-4):485-512. https://doi.org/10.1007/s10571005-4011-5

25. Sahin AR, Erdogan A, Agaoglu PM, Dineri Y, Cakirci AY, Senel ME, Okyay RA, Tasdogan AAM (2019) Novel coronavirus (COVID-19) outbreak: a review of the current literature. EJMO 4:1-7. https://doi.org/10.14744/ejmo.2020.12220

26. Xia H, Lazartigues E (2008) Angiotensin-converting enzyme 2 in the brain: Properties and future directions. J Neurochem 107(6): 1482-1494. https://doi.org/10.1111/j.1471-4159.2008.05723.x

27. Alenina N, Bader M (2019) ACE2 in brain physiology and pathophysiology: evidence from transgenic animal models.
Neurochem Res 44(6):1323-1329. https://doi.org/10.1007/ s11064-018-2679-4

28. Ding Y, He L, Zhang Q, Huang Z, Che X, Hou J, Wang H, Shen H et al (2004) Organ distribution of severe acute respiratory syndrome (SARS) associated coronavirus (SARS-CoV) in SARS patients: mplications for pathogenesis and virus transmission pathways. J Pathol 203(2):622-630. https://doi.org/10.1002/path.1560

29. Xu Z, Shi L, Wang Y, Zhang J, Huang L, Zhang C, Liu S, Zhao P et al (2020) Pathological findings of COVID-19 associated with acute respiratory distress syndrome. Lancet Respir Med 8(4):420 422. https://doi.org/10.1016/S2213-2600(20)30076-X

30. Zhai P, Ding Y, Li Y (2020) The impact of COVID-19 on ischemic stroke. Diagn Pathol 15(1):78. https://doi.org/10.1186/ s13000-020-00994-0

31. Sharifi-Razavi A, Karimi N, Rouhani N (2020) COVID-19 and intracerebral haemorrhage: Causative or coincidental? New Microbes New Infect 35:100669. https://doi.org/10.1016/j.nmni. 2020.100669

32. Radzikowska U et al (2020) Distribution of ACE2, CD147, CD26, and other SARS-CoV-2 associated molecules in tissues and immune cells in health and in asthma, COPD, obesity, hypertension, and COVID-19 risk factors. Allergy. https://doi.org/10. 1111/all.14429, https://doi.org/10.1111/all.14429

33. Ulrich H, Pillat MM (2020) CD147 as a target for COVID-19 treatment: suggested effects of azithromycin and stem cell engagement. Stem Cell Rev Rep 16(3):434-440. https://doi.org/10.1007/ s12015-020-09976-7

34. Cavalcanti AB, Zampieri FG, Rosa RG et al (2020) Hydroxychloroquine with or without azithromycin in mild-tomoderate Covid-19:NEJMoa2019014. https://doi.org/10.1056/ NEJMoa2019014

35. Rosenberg ES, Dufort EM, Udo T, Wilberschied LA, Kumar J, Tesoriero J, Weinberg P, Kirkwood J et al (2020) Association of Treatment with hydroxychloroquine or azithromycin with inhospital mortality in patients with COVID-19 in New York state. JAMA. 323(24):2493-2502. https://doi.org/10.1001/jama.2020. 8630

36. Molina JM, Delaugerre C, Le Goff J, Mela-Lima B, Ponscarme D, Goldwirt L, de Castro N (2020) No evidence of rapid antiviral clearance or clinical benefit with the combination of hydroxychloroquine and azithromycin in patients with severe COVID-19 infection. Med Mal Infect 50(384):30085-30088. https://doi.org/10.1016/j.medmal.2020.03.006

37. Jackson L, Eldahshan W, Fagan SC, Ergul A (2018) Within the brain: the renin angiotensin system. Int J Mol Sci 19(3):876. https://doi.org/10.3390/ijms 19030876

38. Sparks MA, Crowley SD, Gurley SB, Mirotsou M, Coffman TM (2011) Classical renin-angiotensin system in kidney physiology. Compr Physiol 4(3):1201-1228. https://doi.org/10.1002/cphy. c130040

39. Grobe JL, Xu D, Sigmund CD (2008) An intracellular reninangiotensin system in neurons: fact, hypothesis, or fantasy. Physiology (Bethesda) 23:187-193. https://doi.org/10.1152/ physiol.00002.2008

40. Nade VS, Kawale LA, Valte KD, Shendye NV (2015) Cognitive enhancing effect of angiotensin-converting enzyme inhibitors and angiotensin receptor blockers on learning and memory. Indian J Pharm 47(3):263-269. https://doi.org/10.4103/0253-7613. 157114

41. Hamming I, Timens W, Bulthuis M, Lely A, Navis G, van Goor $H$ (2004) Tissue distribution of ACE2 protein, the functional receptor for SARS coronavirus. A first step in understanding SARS pathogenesis. J Pathol 203(2):631-637. https://doi.org/ 10.1002/path. 1570

42. Bennion DM, Haltigan E, Regenhardt RW, Steckelings UM, Sumners C (2015) Neuroprotective mechanisms of the ACE2- 
angiotensin-(1-7)-mas axis in stroke. Curr Hypertens Rep 17(2): 3-3. https://doi.org/10.1007/s11906-014-0512-2

43. Feng Y, Yue X, Xia H, Bindom SM, Hickman PJ, Filipeanu CM, Wu G, Lazartigues E (2008) Angiotensin-converting enzyme 2 overexpression in the subfornical organ prevents the angiotensin II-mediated pressor and drinking responses and is associated with angiotensin II type 1 receptor downregulation. Circ Res 102(6): 729-736. https://doi.org/10.1161/CIRCRESAHA.107.169110

44. Lin Z, Chen Y, Zhang W, Chen AF, Lin S, Morris M (2008) RNA interference shows interactions between mouse brainstem angiotensin AT1 receptors and angiotensin-converting enzyme 2. Exp Physiol 93(5):676-684. https://doi.org/10.1113/expphysiol.2007. 041657

45. Yang W, Huang W, Su S, Li B, Zhao W, Chen S, Gu D (2006) Association study of ACE2 (angiotensin I-converting enzyme 2) gene polymorphisms with coronary heart disease and myocardial infarction in a Chinese Han population. Clin Sci 111(5):333-340. https://doi.org/10.1042/CS20060020

46. Fan Z, Wu G, Yue M, Ye J, Chen Y, Xu B, Shu Z, Zhu J et al (2019) Hypertension and hypertensive left ventricular hypertrophy are associated with ACE2 genetic polymorphism. Life Sci 225:39-45. https://doi.org/10.1016/j.lfs.2019.03.059

47. Harmer D, Gilbert M, Borman R, Clark KL (2002) Quantitative mRNA expression profiling of ACE 2, a novel homologue of angiotensin converting enzyme. FEBS Lett 532(1-2):107-110. https://doi.org/10.1016/s0014-5793(02)03640-2

48. Gallagher PE, Chappell MC, Ferrario CM, Tallant EA (2006) Distinct roles for ANG II and ANG-(1-7) in the regulation of angiotensin-converting enzyme 2 in rat astrocytes. Am J Physiol Cell Physiol 290(2):C420-C426. https://doi.org/10.1152/ajpcell. 00409.2004

49. Chen R, Wang K, Yu J, Chen Z, Wen C, Xu Z (2020) The spatial and cell-type distribution of SARS-CoV-2 receptor ACE2 in human and mouse brain. bioRxiv. https://doi.org/10.1101/2020.04. 07.030650

50. Doobay MF, Talman LS, Obr TD, Tian X, Davisson RL, Lazartigues E (2007) Differential expression of neuronal ACE2 in transgenic mice with overexpression of the brain reninangiotensin system. Am J Phys Regul Integr Comp Phys 292(1):R373-R381. https://doi.org/10.1152/ajpregu.00292.2006

51. Bertram S, Heurich A, Lavender H, Gierer S, Danisch S, Perin P, Lucas JM, Nelson PS et al (2012) Influenza and SARScoronavirus activating proteases TMPRSS 2 and HAT are expressed at multiple sites in human respiratory and gastrointestinal tracts. PLoS One 7(4):e35876. https://doi.org/10.1371/journal. pone. 0035876

52. Sungnak W, Huang N, Bécavin C, Berg M, Queen R, Litvinukova M, Talavera-López C, Maatz H et al (2020) SARS-CoV-2 entry factors are highly expressed in nasal epithelial cells together with innate immune genes. Nat Med 26(5):681-687. https://doi.org/10. 1038/s41591-020-0868-6

53. Li X, Zai J, Zhao Q, Nie Q, Li Y, Foley BT, Chaillon A (2020) Evolutionary history, potential intermediate animal host, and cross-species analyses of SARS-CoV-2. J Med Virol 92(6):602611. https://doi.org/10.1002/jmv.25731

54. Ueha R, Kondo K, Kagoya R, Shichino S, Ueha S, Yamasoba T Background mechanisms of olfactory dysfunction in COVID-19: expression of ACE2, TMPRSS2, and Furin in the nose and olfactory bulb in human and mice. bioRxiv (Preprint). https://doi.org/ 10.1101/2020.05.15.097352

55. Wu C, Ye D, Mullick AE et al (2020) Effects of renin-angiotensin inhibition on ACE2 and TMPRSS2 expression: insights into COVID-19. Preprint. bioRxiv;2020.06.08.137331. Published 2020 Jun 18. https://doi.org/10.1101/2020.06.08.137331

56. Hoffmann M, Kleine-Weber H, Schroeder S, Kruger N, Herrler T, Erichsen S, Schiergens TS, Herrler G et al (2020) SARS-CoV-2 cell entry depends on ACE2 and TMPRSS2 and is blocked by a clinically proven protease inhibitor. Cell 181(2):271-280 e278. https://doi.org/10.1016/j.cell.2020.02.052

57. Fodoulian L, Tuberosa J, Rossier D, Landis BN, Carleton A, Rodriguez I (2020) SARS-CoV-2 receptor and entry genes are expressed by sustentacular cells in the human olfactory neuroepithelium. Biorxiv Preprint:1-16. https://doi.org/10.1101/ 2020.03.31.013268

58. Durante MA, Kurtenbach S, Sargi ZB, Harbour JW, Choi R, Kurtenbach S, Goss GM, Matsunami H et al (2020) Single-cell analysis of olfactory neurogenesis and differentiation in adult humans. Nat Neurosci 23(3):323-326. https://doi.org/10.1038/ s41593-020-0587-9

59. Saavedra JM (2020) COVID-19, angiotensin receptor blockers, and the brain. Cell Mol Neurobiol 40(5):667-674. https://doi. org/10.1007/s10571-020-00861-y

60. Mueller SM, Heistad DD (1980) Effect of chronic hypertension on the blood-brain barrier. Hypertension 2(6):809-812. https://doi. org/10.1161/01.hyp.2.6.809

61. Buttler L, Jordão MT, Fragas MG, Ruggeri A, Ceroni A, Michelini LC (2017) Maintenance of blood-brain barrier integrity in hypertension: a novel benefit of exercise training for autonomic control. Front Physiol 8:1048. https://doi.org/10.3389/fphys. 2017.01048

62. Mahmudpour M, Roozbeh J, Keshavarz M, Farrokhi S, Nabipour I (2020) COVID-19 cytokine storm: the anger of inflammation. Cytokine 133:155151. https://doi.org/10.1016/j.cyto.2020. 155151

63. Pacurari M, Kafoury R, Tchounwou PB, Ndebele K (2014) The renin-angiotensin-aldosterone system in vascular inflammation and remodeling. Int J Inflamm 2014:689360-689313. https://doi. org/10.1155/2014/689360

64. Duprez DA (2006) Role of the renin-angiotensin-aldosterone system in vascular remodeling and inflammation: a clinical review. J Hypertens 24(6):983-991. https://doi.org/10.1097/01.hjh. 0000226182.60321 .69

65. Li Y, Zeng Z, Cao Y, Liu Y, Ping F, Liang M, Xue Y, Xi C et al (2016) Angiotensin-converting enzyme 2 prevents lipopolysaccharide-induced rat acute lung injury via suppressing the ERK1/2 and NF-kappaB signaling pathways. Sci Rep 6: 27911. https://doi.org/10.1038/srep27911

66. Chen X et al (2020) Detectable serum SARS-CoV-2 viral load (RNAaemia) is closely correlated with drastically elevated interleukin 6 (IL-6) level in critically ill COVID-19 patients. Clin Infect Dis:ciaa449. https://doi.org/10.1093/cid/ciaa449

67. Xu ZS, Shu T, Kang L, Wu D, Zhou X, Liao BW, Sun XL, Zhou $X$ et al (2020) Temporal profiling of plasma cytokines, chemokines and growth factors from mild, severe and fatal COVID-19 patients. Signal Transduct Target Ther 5(1):100. https://doi.org/10.1038/s41392-020-0211-1

68. Wan S, Yi Q, Fan S, Lv J, Zhang X, Guo L, Lang C, Xiao Q et al (2020) Relationships among lymphocyte subsets, cytokines, and the pulmonary inflammation index in coronavirus (COVID-19) infected patients. Br J Haematol 189(3):428-437. https://doi.org/ 10.1111/bjh.16659

69. Sarzi-Puttini P, Giorgi V, Sirotti S, Marotto D, Ardizzone S, Rizzardini G, Antinori S, Galli M (2020) COVID-19, cytokines and immunosuppression: what can we learn from severe acute respiratory syndrome? Clin Exp Rheumatol 38(2):337-342

70. McGonagle D, Sharif K, O'Regan A, Bridgewood C (2020) The role of cytokines including interleukin-6 in COVID-19 induced pneumonia and macrophage activation syndrome-like disease. Autoimmun Rev 19(6):102537. https://doi.org/10.1016/j.autrev. 2020.102537

71. Han H, Ma Q, Li C, Liu R, Zhao L, Wang W, Zhang P, Liu X et al (2020) Profiling serum cytokines in COVID-19 patients reveals 
IL-6 and IL-10 are disease severity predictors. Emerg Microbes Infect 9(1):1123-1130. https://doi.org/10.1080/22221751.2020. 1770129

72. Costela-Ruiz VJ, Illescas-Montes R, Puerta-Puerta JM, Ruiz C, Melguizo-Rodríguez L (2020) SARS-CoV-2 infection: the role of cytokines in COVID-19 disease. Cytokine Growth Factor Rev S1359-6101(20):30109-3010X. https://doi.org/10.1016/j. cytogfr.2020.06.001

73. Welcome MO (2020) Cellular mechanisms and molecular signaling pathways in stress-induced anxiety, depression, and bloodbrain barrier inflammation and leakage. Inflammopharmacology 28(3):643-665. https://doi.org/10.1007/s10787-020-00712-8

74. Iddir M, Brito A, Dingeo G, Fernandez del Campo SS, Samouda H, la Frano MR, Bohn T (2020) Strengthening the immune system and reducing inflammation and oxidative stress through diet and nutrition: considerations during the COVID-19 crisis. Nutrients. 12(6):1562. https://doi.org/10.3390/nu12061562

75. Java A, Apicelli AJ, Liszewski MK, Coler-Reilly A, Atkinson JP, Kim AHJ, Kulkarni HS (2020) The complement system in COVID-19: friend and foe? JCI Insight 5(15):140711. https:/ doi.org/10.1172/jci.insight.140711

76. Di Virgilio F, Tang Y, Sarti AC, Rossato M (2020) A rationale for targeting the $\mathrm{P} 2 \mathrm{X} 7$ receptor in coronavirus disease $19 . \mathrm{Br} \mathrm{J}$ Pharmacol. https://doi.org/10.1111/bph.15138

77. Grygorowicz T, Sulejczak D, Struzynska L (2011) Expression of purinergic $\mathrm{P} 2 \mathrm{X} 7$ receptor in rat brain during the symptomatic phase of experimental autoimmune encephalomyelitis and after recovery of neurological deficits. Acta Neurobiol Exp (Wars) 71(1):65-73

78. Russell B, Moss C, Rigg A, Van Hemelrijck M (2020) COVID-19 and treatment with NSAIDs and corticosteroids: should we be limiting their use in the clinical setting? Ecancermedicalscience 14:1023. https://doi.org/10.3332/ecancer.2020.1023

79. Schiffrin EL, Flack JM, Ito S, Muntner P, Webb RC (2020) Hypertension and COVID-19. Am J Hypertens 33(5):373-374. https://doi.org/10.1093/ajh/hpaa057

80. Fang L, Karakiulakis G, Roth M (2020) Are patients with hypertension and diabetes mellitus at increased risk for COVID-19 infection? Lancet Respir Med 8(4):e21. https://doi.org/10.1016/ S2213-2600(20)30116-8

81. Nath A (2020) Neurologic complications of coronavirus infections. Neurology. 94(19):809-810. https://doi.org/10.1212/ WNL.0000000000009455

82. Butowt R, Bilinska K (2020) SARS-CoV-2: Olfaction, brain infection, and the urgent need for clinical samples allowing earlier virus detection. ACS Chem Neurosci 11(9):1200-1203. https:// doi.org/10.1021/acschemneuro.0c00172

83. Shen Q, Wang Y, Kokovay E, Lin G, Chuang SM, Goderie SK, Roysam B, Temple S (2008) Adult SVZ stem cells lie in a vascular niche: a quantitative analysis of niche cell-cell interactions. Cell Stem Cell 3(3):289-300. https://doi.org/10.1016/j.stem. 2008.07.026

84. Kim MS, Lee GH, Kim YM, Lee BW, Nam HY, Sim UC, Choo SJ, Yu SW et al (2017) Angiotensin II causes apoptosis of adult hippocampal neural stem cells and memory impairment through the action on AMPK-PGC1 $\alpha$ signaling in heart failure. Stem Cells Transl Med 6(6):1491-1503. https://doi.org/10.1002/sctm.160382

85. Saad M, Omrani AS, Baig K, Bahloul A, Elzein F, Matin MA, Selim MAA, Mutairi MA et al (2014) Clinical aspects and outcomes of 70 patients with Middle East respiratory syndrome coronavirus infection: a single-center experience in Saudi Arabia. Int J Infect Dis 29:301-306. https://doi.org/10.1016/j.ijid.2014.09. 003

86. Ivanova N, Tchekalarova J (2019) The potential therapeutic capacity of inhibiting the brain renin-angiotensin system in the treatment of co-morbid conditions in epilepsy. CNS Drugs 33(11):1101-1112. https://doi.org/10.1007/s40263-019-00678-4

87. Gouveia TL, Frangiotti MI, de Brito JM et al (2012) The levels of renin-angiotensin related components are modified in the hippocampus of rats submitted to pilocarpine model of epilepsy. Neurochem Int 61(1):54-62. https://doi.org/10.1016/j.neuint. 2012.04.012

88. Wang H, Tang X, Fan H, Luo Y, Song Y, Xu Y, Chen Y (2020) Potential mechanisms of hemorrhagic stroke in elderly COVID-19 patients. Aging (Albany NY) 12(11):10022-10034. https://doi. org/10.18632/aging.103335

89. Beyrouti R, Adams ME, Benjamin L, Cohen H, Farmer SF, Goh YY, Humphries F, Jäger HR et al (2020) Characteristics of ischaemic stroke associated with COVID-19. J Neurol Neurosurg Psychiatry 91(8):889-891. https://doi.org/10.1136/jnnp-2020323586

90. Kaushik P, Kaushik M, Parveen S, Tabassum H, Parvez S (2020) Cross-talk between key players in patients with COVID-19 and ischemic stroke: a review on neurobiological insight of the pandemic. Mol Neurobiol:1-8. https://doi.org/10.1007/s12035-02002072-4

91. Avula A, Nalleballe K, Narula N, Sapozhnikov S, Dandu V, Toom S, Glaser A, Elsayegh D (2020) COVID-19 presenting as stroke. Brain Behav Immun S0889-1591(0820):30685-30681. https://doi.org/10.1016/j.bbi.2020.04.077

92. Fletcher-Sandersjoo A, Bellander BM (2020) Is COVID-19 associated thrombosis caused by overactivation of the complement cascade? A literature review. Thromb Res 194:36-41. https:// doi.org/10.1016/j.thromres.2020.06.027

93. Chauhan AJ, Wiffen LJ, Brown TP (2020) COVID-19: A collision of complement, coagulation and inflammatory pathways. J Thromb Haemost 18:2110-2117. https://doi.org/10.1111/jth. 14981

94. Moshayedi P, Ryan TE, Mejia LLP, Nour M, Liebeskind DS (2020) Triage of acute ischemic stroke in confirmed COVID-19: large vessel occlusion associated with coronavirus infection. Front Neurol 11:353. https://doi.org/10.3389/fneur.2020.00353

95. Wright J, Huang C, Strbian D, Sundararajan S (2014) Diagnosis and management of acute cerebellar infarction. Stroke 45(4):e56e58. https://doi.org/10.1161/STROKEAHA.114.004474

96. Pedroso JL, Vale TC, Braga-Neto P, Dutra LA, França Jr MC, Teive HAG, Barsottini OGP (2019) Acute cerebellar ataxia: differential diagnosis and clinical approach. Arq Neuropsiquiatr 77(3):184-193. https://doi.org/10.1590/0004-282X20190020

97. Finocchi C, Sassos D (2017) Headache and arterial hypertension. Neurol Sci 38(Suppl 1):67-72. https://doi.org/10.1007/s10072017-2893-x

98. Headache Classification Committee of the International Headache Society (IHS) (2013) The international classification of headache disorders, 3rd edition (beta version). Cephalalgia. 33(9):629-808. https://doi.org/10.1177/0333102413485658

99. Lagman-Bartolome AM, Gladstone J (2014) Metabolic headaches. Neurol Clin 32(2):451-469. https://doi.org/10.1016/j. ncl.2013.11.011

100. Tikellis C, Thomas MC (2012) Angiotensin-converting enzyme 2 (ACE2) is a key modulator of the renin angiotensin system in health and disease. Int J Pept 2012:256294-256298. https://doi. org/10.1155/2012/256294

101. Conti P, D'Ovidio C, Conti C et al (2019) Progression in migraine: role of mast cells and pro-inflammatory and anti-inflammatory cytokines. Eur J Pharmacol 844:87-94. https://doi.org/10.1016/j. ejphar.2018.12.004

102. Rambe AS, Sjahrir H, Machfoed MH (2017) Tumour necrosis factor-alpha, Interleukin-1 and Interleukin-6 serum levels and its correlation with pain severity in chronic tension-type headache patients: analysing effect of dexketoprofen administration. Open 
Access Maced J Med Sci 5(1):54-57. https://doi.org/10.3889/ oamjms.2017.024

103. Filatov A, Sharma P, Hindi F, Espinosa PS (2020) Neurological complications of coronavirus disease (COVID-19): encephalopathy. Cureus. 12(3):e7352. https://doi.org/10.7759/cureus.7352

104. Vaughan CJ, Delanty N (2000) Hypertensive emergencies. Lancet. 356(9227):411-417. https://doi.org/10.1016/S01406736(00)02539-3

105. Immink RV, van den Born BJ, van Montfrans GA, Koopmans RP, Karemaker JM, van Lieshout JJ (2004) Impaired cerebral autoregulation in patients with malignant hypertension. Circulation. 110(15):2241-2245. https://doi.org/10.1161/01.CIR. 0000144472.08647 .40

106. Schwartz RB, Jones KM, Kalina P et al (1992) Hypertensive encephalopathy: findings on CT, MR imaging, and SPECT imaging in 14 cases. AJR Am J Roentgenol 159(2):379-383. https://doi. org/10.2214/ajr.159.2.1632361

107. Lippi G, Wong J, Henry BM (2020) Hypertension in patients with coronavirus disease 2019 (COVID-19): a pooled analysis. Pol Arch Intern Med 130(4):304-309. https://doi.org/10.20452/ pamw. 15272

108. Wysocki J, Ye M, Rodriguez E, González-Pacheco FR, Barrios C, Evora K, Schuster M, Loibner H et al (2010) Targeting the degradation of angiotensin II with recombinant angiotensinconverting enzyme 2: prevention of angiotensin II-dependent hypertension. Hypertension. 55(1):90-98. https://doi.org/10.1161/ HYPERTENSIONAHA. 109.138420

109. Vintila I, Roman-Filip C, Rociu C (2010) Hypoxic-ischemic encephalopathy in adult. Acta Medica Transilvanica 2(3):189-192

110. Bathla G, Hegde AN (2013) MRI and CT appearances in metabolic encephalopathies due to systemic diseases in adults. Clin Radiol 68(6):545-554. https://doi.org/10.1016/j.crad.2012.05.021

111. Zheng YY, Ma YT, Zhang JY, Xie X (2020) COVID-19 and the cardiovascular system. Nat Rev Cardiol 17(5):259-260. https:// doi.org/10.1038/s41569-020-0360-5

112. Oudit GY, Crackower MA, Backx PH, Penninger JM (2003) The role of ACE2 in cardiovascular physiology. Trends Cardiovasc
Med 13(3):93-101. https://doi.org/10.1016/s1050-1738(02) 00233-5

113. Patel VB, Zhong JC, Grant MB, Oudit GY (2016) Role of the ACE2/angiotensin 1-7 Axis of the renin-angiotensin system in heart failure. Circ Res 118(8):1313-1326. https://doi.org/10. 1161/CIRCRESAHA.116.307708

114. Zhang C, Shi L, Wang FS (2020) Liver injury in COVID-19: management and challenges. Lancet Gastroenterol Hepatol 5(5): 428-430. https://doi.org/10.1016/S2468-1253(20)30057-1

115. Seifter JL, Samuels MA (2011) Uremic encephalopathy and other brain disorders associated with renal failure. In: Seminars in neurology, vol 02. (C) Thieme Medical Publishers, pp 139-143

116. Lisowska-Myjak B (2014) Uremic toxins and their effects on multiple organ systems. Nephron Clin Pract 128(3-4):303-311. https://doi.org/10.1159/000369817

117. Cheng Y, Luo R, Wang K, Zhang M, Wang Z, Dong L, Li J, Yao $\mathrm{Y}$ et al (2020) Kidney disease is associated with in-hospital death of patients with COVID-19. Kidney Int 97(5):829-838. https:// doi.org/10.1016/j.kint.2020.03.005

118. Pan XW, Xu D, Zhang H, Zhou W, Wang LH, Cui XG (2020) Identification of a potential mechanism of acute kidney injury during the COVID-19 outbreak: a study based on single-cell transcriptome analysis. Intensive Care Med 46(6):1114-1116. https:// doi.org/10.1007/s00134-020-06026-1

119. Meng J, Xiao G, Zhang J, He X, Ou M, Bi J, Yang R, Di W et al (2020) Renin-angiotensin system inhibitors improve the clinical outcomes of COVID-19 patients with hypertension. Emerg Microbes Infect 9(1):757-760. https://doi.org/10.1080/ 22221751.2020 .1746200

120. Malek M (2018) Brain consequences of acute kidney injury: focusing on the hippocampus. Kidney Res Clin Pract 37(4):315322. https://doi.org/10.23876/j.krcp.18.0056

121. Mizuiri S, Ohashi Y (2015) ACE and ACE2 in kidney disease. World J Nephrol 4(1):74-82. https://doi.org/10.5527/wjn.v4.i1.74

Publisher's Note Springer Nature remains neutral with regard to jurisdictional claims in published maps and institutional affiliations. 